\author{
PAWEl BREZdeń \\ Waldemar SpalleK \\ Uniwersytet Wrocławski
}

\title{
Efektywność firm korporacyjnych o dobrym standingu w województwie dolnośląskim w ujęciu przestrzennym
}

\author{
POJECIE FIRMY KORPORACYJNEJ O DOBRYM STANDINGU
}

Pojęcie firmy korporacyjnej odnosi się najczęściej do dużych, organizacyjnie rozgałęzionych przedsiębiorstw (spółek) funkcjonujących w skali międzynarodowej. W literaturze na oznaczenie tego typu działalności używa się wielu różnych terminów: przedsiębiorstwo wielonarodowe, korporacja międzynarodowa, globalna, transnarodowa, ponadnarodowa, multinarodowa. Najogólniej można stwierdzić, że są to przedsiębiorstwa, które kontrolują aktywa zlokalizowane w dwóch lub większej liczbie krajów (Budnikowski, Kawecka-Wyrzykowska 1996, Pierścionek 1998). Dlatego wyżej wymienione terminy dotyczą przedsiębiorstw, które dokonały procesu internacjonalizacji swojej działalności.

Pojęcie firmy korporacyjnej pojawia się także w kontekście segmentacji rynku dokonywanej przez różnorodne instytucje usługowe, w tym szczególnie przez finansowe. Jej celem jest identyfikacja określonej grupy docelowej odbiorców, do których skierowane są oferty produktów adekwatne do ich potrzeb. W tym marketingowym ujęciu firma korporacyjna traktowana jest jako klient korporacyjny.

Niniejsze opracowanie dotyczy efektywności firm korporacyjnych w województwie dolnośląskim, które zostały wybrane na podstawie kryterium marketingowego funkcjonującego w instytucjach bankowych. Na potrzeby marketingu bankowego wydziela się przeważnie trzy grupy przedsiębiorstw (Jaworski, Krzyżkiewicz, Kosiński 2003):

- wielkie (strategiczne), o mocnej pozycji finansowej, ocenianie ze względu na rozmiary powierzonych lokat bankowych i zaciąganych kredytów, starające się często narzucać bankowi własne warunki współpracy i sprowadzające marże kredytowe do minimalnych poziomów. Stosunki z tymi partnerami są układane na zasadzie indywidualnych negocjacji;

- duże, będące dla banku klientem o wyższej lub niższej kategorii w zależności od posiadanej kondycji finansowej. Działania w stosunku do tej grupy klientów zmierzają z reguły w kierunku identyfikacji klientów najbardziej dynamicznych i solidnych;

- liczne małe i średnie (MSP), charakteryzujące się bardzo często dużym zapotrzebowaniem na kredyty inwestycyjno-modrenizacyjne, których kredytowanie niejednokrotnie jest uzależnione od posiadanych zabezpieczeń majątkowych, często przekraczających rozmiary tych zabezpieczeń. 
Za klientów bankowości korporacyjnej uważne są przedsiębiorstwa wielkie (strategiczne) i duże. Brak jednak na rynku jednoznacznego kryterium umożliwiającego identyfikację klienta korporacyjnego. W niniejszym opracowaniu do identyfikacji firm korporacyjnych przyjęto wielkość 5 mln zł przychodów osiąganych w danym roku sprawozdawczym. Powyższa wysokość przychodów jest przyjmowana przez wiele instytucji finansowych do identyfikacji klientów korporacyjnych na rynku.

Instytucje finansowe przy sprzedaży, szczególnie produktów kredytowych, posługują się różnymi metodami oceny wiarygodności kredytowej podmiotu. Do takich metod oceny należy m.in. standing finansowy. Jest to ocena przyznawana przez bank podmiotom gospodarczym, zwykle dokonywana przed udzieleniem kredytu, przed emisją obligacji czy akcji itp. Od niej zależy późniejszy koszt pozyskania kapitału na rynku lub marża narzucana przez bank przy udzielaniu kredytu. Ocena ta jest częścią ogólnej oceny standingu firmy, który jest często utożsamiany z pojęciem dobrej reputacji handlowej (goodwill).

W niniejszym opracowaniu dokonane analizy firm korporacyjnych o dobrym standingu zostały przeprowadzone na podstawie bazy podmiotów gospodarczych w 2006 r. zidentyfikowanych na podstawie ich wyników finansowych i kryteriów wymienionych przez wywiadownię gospodarczą Coface InterCredit (Baza firm... 2007). W bazie podmiotów wśród informacji dotyczących lokalizacji firm korporacyjnych, ich kapitału własnego, wyniku finansowego, istotną pozycją jest wielkość uzyskiwanych przychodów ze sprzedaży. W tym wypadku pojęcie przychodów ze sprzedaży ma charakter zagregowany i obejmuje: przychody netto ze sprzedaży produktów, towarów i materiałów, pozostałe przychody operacyjne oraz przychody finansowe.

Podmioty, szczególnie korporacyjne o dobrym standingu, odgrywają ważną rolę w gospodarkach lokalnych danego regionu, gdyż przyczyniają się do tworzenia korzystnych uwarunkowań rozwoju regionalnego obszarów, na których operują. Wynika to w dużej mierze z możliwości realizowania przez powyższe firmy procesów inwestycyjnych generujących zarówno wzrost gospodarczy, jak i pożądane przekształcenia strukturalne w obszarach problemowych. Skutkuje to osiaganiem wyższego poziomu rozwoju gospodarczego takich obszarów.

\section{CHARAKTERYSTYKA FIRM KORPORACYJNYCH}

O DOBRYM STANDINGU W WOJEWÓDZTWIE DOLNOŚLĄSKIM

Na koniec 2006 r. w województwie dolnośląskim funkcjonowało 1019 firm korporacyjnych o dobrym standingu. Stanowiły one niespełna 1,5\% ogółu podmiotów gospodarczych (bez osób fizycznych) w regionie. Analizowane firmy odgrywały istotną rolę w kreowaniu rynku pracy w województwie. Ich udział wśród ogółu zatrudnionych w regionie wynosił ponad $25 \%$.

Odsetek firm korporacyjnych o dobrym standingu w 2006 r. w znacznej części województw Polski stanowił około 50\% wszystkich firm osiagających przychody powyżej $5 \mathrm{mln}$ zł. W przypadku województwa dolnośląskiego ten udział był nieco niższy i ukształtował się na poziomie $46 \%$ (ryc. 1). Przyczyny takiego stanu mogą wynikać z ukształtowanej struktury gospodarczej regionu w okresach wcześniejszych. Była ona w dużej mierze determinowana rodzajami działalności, które w okresie transformacji gospodarczej kraju przeżywały szczególne trudności, np. górnictwo węgla kamiennego, przemysł włókienniczy, elektroniczno-elektrotechniczny czy maszynowy. 


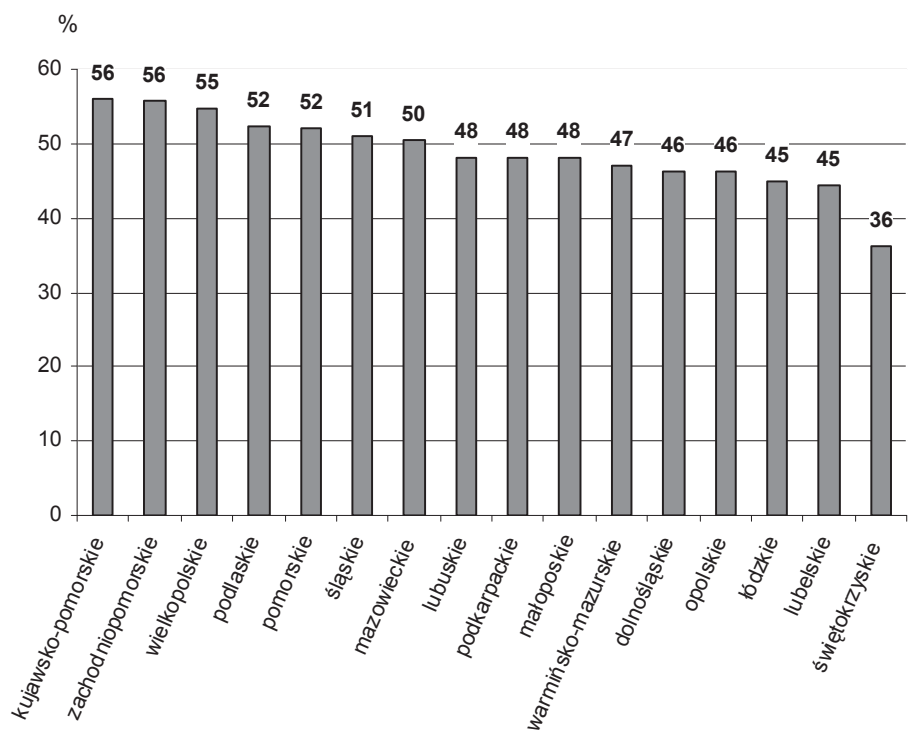

Ryc. 1. Odsetek firm o dobrym standingu w grupie podmiotów o przychodach powyżej $5 \mathrm{mln}$ zł według województw

Źródło: opracowanie własne na podstawie: Baza firm... (2007), Podmioty gospodarcze... (2007)

Pod względem liczebności firm korporacyjnych o dobrym standingu w 2006 r. województwo uplasowało się na wysokiej piątej pozycji w kraju (7,1\% ogólnej liczby firm tego typu w Polsce), po województwach: mazowieckim (18,2\%), śląskim (13\%), wielkopolskim $(11,5 \%)$ i małopolskim $(7,8 \%)$, a przed pomorskim $(6,8 \%)$ i łódzkim $(6,1 \%)$. Najmniejszy udział w badanej zbiorowości firm był charakterystyczny dla województw: lubuskiego, opolskiego i świętokrzyskiego i kształtował się na poziomie od 2,5\% do 1,9\%.

Nie wszystkie firmy o dobrym standingu w województwie dolnośląskim prowadziły swoją działalność z zyskiem. Udział firm wykazujących stratę netto stanowił 11\% ogółu badanej zbiorowości. Przyczyny takiej sytuacji miały złożony charakter. W wielu podmiotach prowadzenie działalności ze stratą netto w 2006 r. było skutkiem realizowanych procesów inwestycyjnych związanych z przekształcaniem lub dywersyfikacją prowadzonej działalności produkcyjnej lub usługowej bądź efektem zrealizowanych przekształceń własnościowych.

Badanie struktury firm o dobrym standingu według rodzajów działalności wykazało, iż największy odsetek tych firm był charakterystyczny dla przetwórstwa przemysłowego i górnictwa. Udział podmiotów powyższego rodzaju działalności stanowił 33\% ogółu badanej zbiorowości. Kolejne pozycje ze znaczącymi udziałami zajmowały: handel hurtowy (23\%), budownictwo (14\%) i handel detaliczny (8\%). Łącznie wskazane rodzaje działalności były charakterystyczne dla blisko $80 \%$ firm korporacyjnych o dobrym standingu w województwie (ryc. 2).

Odsetek podmiotów o wskazanych rodzajach działalności kształtował się także na podobnym poziomie w zakresie zatrudnienia. Znaczące różnice dotyczyły jednak wewnętrznej struktury udziału podmiotów o określonych rodzajach działalności w ogólnym zatrudnieniu. Udział podmiotów związanych z przetwórstwem przemysłowym i górnictwem w zatrudnieniu był jeszcze wyższy niż w przypadku struktury podmiotów według rodzajów działalności 


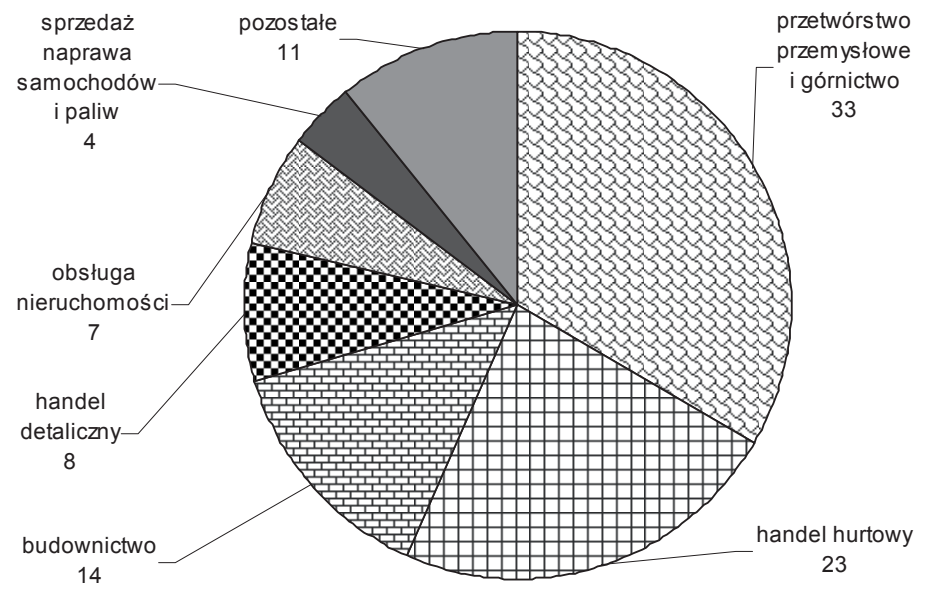

Ryc. 2. Struktura firm korporacyjnych o dobrym standingu według rodzaju działalności w \%

Źródło: opracowanie własne na podstawie: Baza firm... (2007)

i wynosił ponad 47\%. Na drugiej pozycji uplasowało się budownictwo z ponad $14 \%$ udziałem w rynku zatrudnienia badanej zbiorowości podmiotów. Następne pozycje zajęły: handel hurtowy i detaliczny (odpowiednio 10\% i 5\%). W obu powyższych rodzajach działalności ich udział w rynku zatrudnienia był niższy niż w przypadku struktury według rodzajów działalności (ryc. 3).

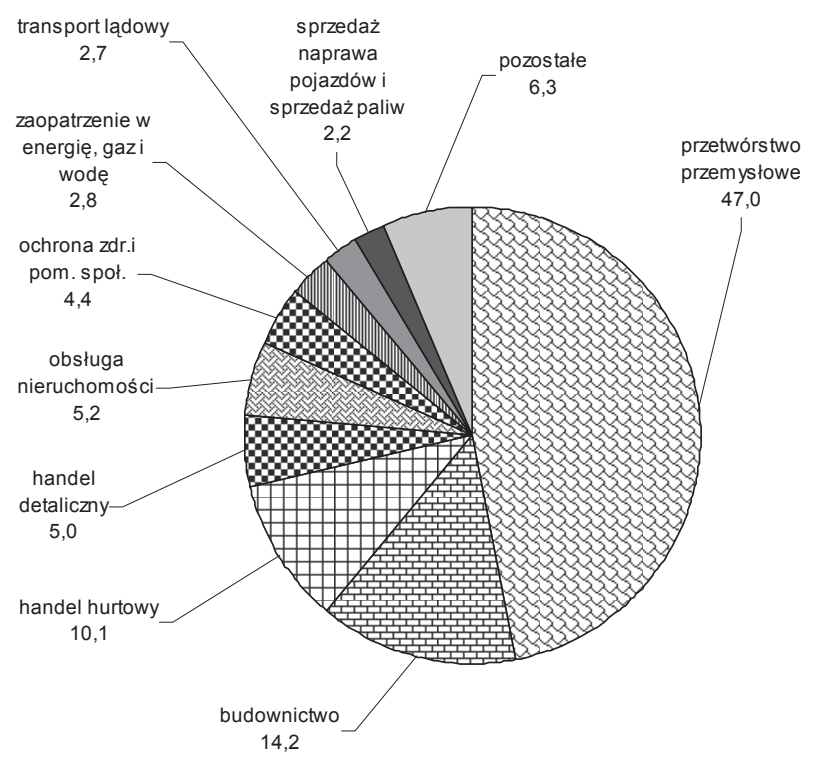

Ryc. 3. Struktura firm korporacyjnych o dobrym standingu według zatrudnienia $\mathrm{w} \%$ Źródło: opracowanie własne na podstawie: Baza firm... (2007) 
Nasycenie firmami korporacyjnymi o dobrym standingu w 2006 r. wykazywało znaczne przestrzenne zróżnicowanie w województwie dolnośląskim w układzie powiatów (ryc. 4). Największe miało miejsce w powiatach wschodniej części województwa, szczególnie we Wrocławiu, powiecie wrocławskim, świdnickim oraz w Jeleniej Górze. Ponadto stosunkowo wysoki poziom nasycenia badanymi podmiotami był charakterystyczny dla powiatów związanych z wrocławskim obszarem metropolitalnym bądź położonych w bliskim jego sąsiedztwie. Natężenie występowania wskazanych firm jest związane z obecnością dużej aglomeracji miejsko-przemysłowej.

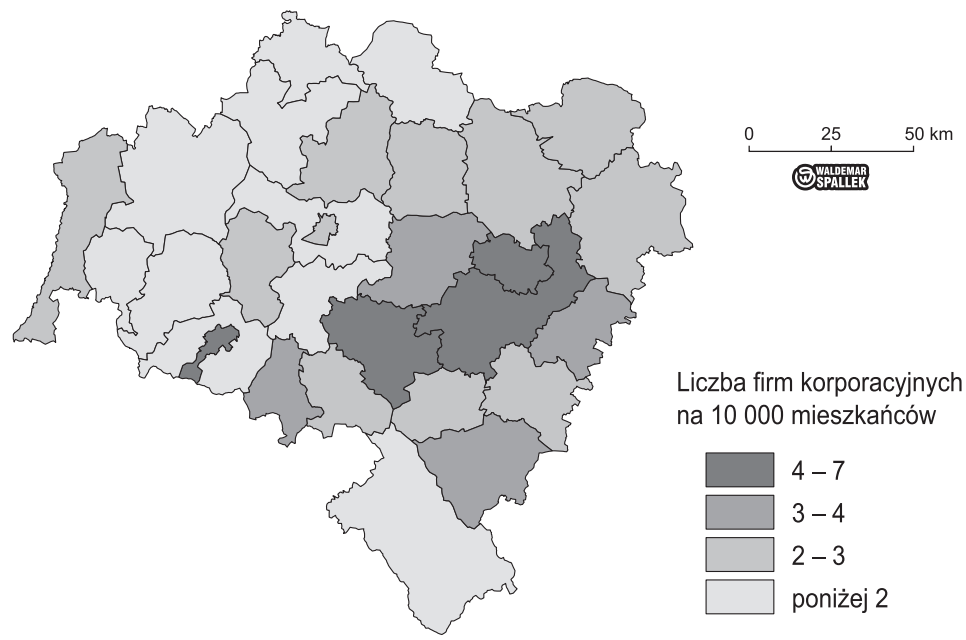

Ryc. 4. Nasycenie firmami korporacyjnymi o dobrym standingu w województwie dolnośląskim w 2006 r.

Źródło: opracowanie własne na podstawie: Baza firm... (2007)

\section{WYBRANE ZAGADNIENIA EFEKTYWNOŚCI FIRM KORPORACYJNYCH}

O DOBRYM STANDINGU W PRZESTRZENI WOJEWÓDZTWA

Badanie pełnej efektywności ekonomicznej określonych grup podmiotów gospodarczych w Polsce w ujęciach przestrzennych napotyka na szereg trudności związanych szczególnie z brakiem szerokiego spektrum informacji ekonomicznych opisujących efekty ich funkcjonowania. Wobec powyższego analiza efektywności firm korporacyjnych o dobrym standingu w województwie dolnośląskim dotyczyć będzie jedynie wybranych elementów wspomnianej efektywności determinowanych zakresem posiadanych danych.

Wybrane wskaźniki rentowności badanych podmiotów wykazują znaczne zróżnicowanie w zależności od rodzaju prowadzonej przez nie działalności (ryc. 5). Najwyższą wartość przychodu ze sprzedaży na 1 zatrudnionego osiagają firmy prowadzące działalność w handlu hurtowym i detalicznym. Wyniki osiagane przez firmy w tych rodzajach działalności są niemal dwukrotnie wyższe (w przypadku handlu hurtowego) niż osiagane w przetwórstwie przemysłowym, a jeszcze większe w przypadku obsługi nieruchomości czy budownictwa. 


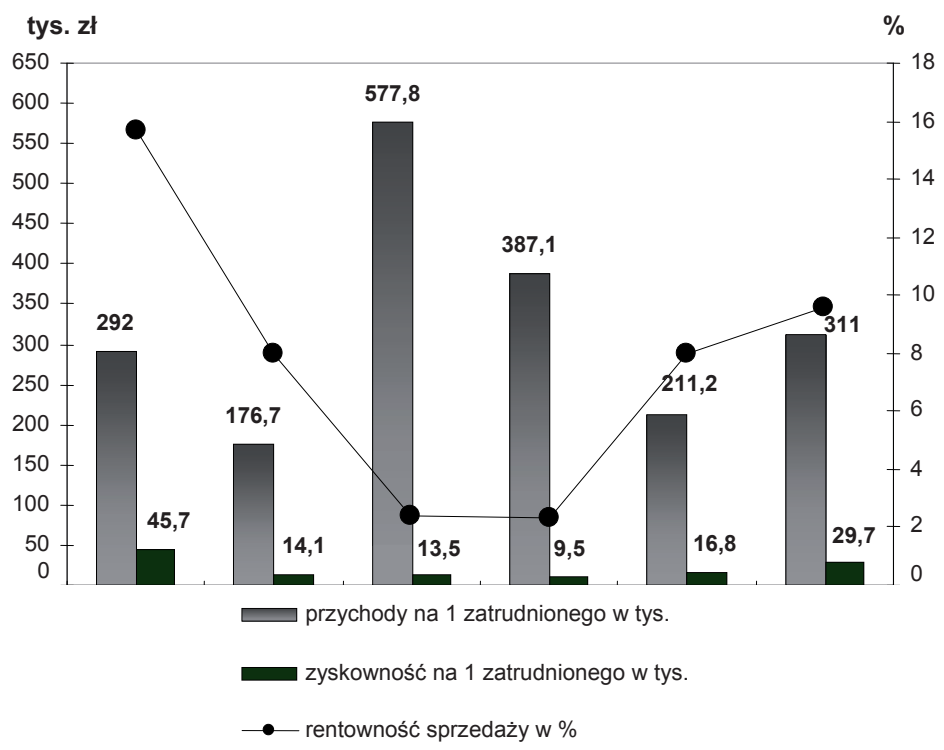

Ryc. 5. Wybrane wskaźniki rentowności firm korporacyjnych o dobrym standingu w województwie dolnośląskim według głównych rodzajów działalności

Źródło: opracowanie własne na podstawie: Baza firm... (2007)

Korzystniejsze relacje ekonomiczne dla przetwórstwa przemysłowego, obsługi nieruchomości czy budownictwa występują w zyskowności na 1 zatrudnionego i rentowności sprzedaży. Szczególnie korzystne relacje w stosunku do pozostałych rodzajów działalności występują w przetwórstwie przemysłowym, które charakteryzuje się kilkakrotnie wyższym poziomem rentowności sprzedaży niż handel detaliczny czy hurtowy. W przypadku przetwórstwa przemysłowego poziom rentowności sprzedaży wynosił $16 \%$, natomiast handlu detalicznego i hurtowego zawierał się w przedziale od 2,5 do 3\%.

Powyższy współczynnik informuje o udziale zysku netto w wartości przychodów ze sprzedaży. Im jest on niższy, tym większa wartość sprzedaży musi zostać zrealizowana do osiagnięcia określonej kwoty zysku. Zwiększenie rentowności jest jednoznaczne ze wzrostem efektywności sprzedaży, co bez wątpienia jest tendencją korzystną. Z reguły niska zyskowność może występować przy krótkim cyklu produkcyjnym lub sprzedaży, natomiast wyższa jest typowa przy dłuższym cyklu obrotowym produkcji lub sprzedaży (ĆwiąkałaMałys, Maksimowicz 1997). Wskazane prawidłowości potwierdzają się w badanej zbiorowości podmiotów szczególnie w przypadku przetwórstwa przemysłowego i działalności handlowej hurtowej i detalicznej.

Skala wielkości przychodów ze sprzedaży uzyskiwanych przez firmy korporacyjne o dobrym standingu w województwie jest znacznie zróżnicowana w ujęciu przestrzennym (ryc. 6). Największe wartości przychodów w mln zł przypadające na 1 firmę korporacyjną (czyli największe firmy korporacyjne) miały miejsce w powiatach: lubińskim, polkowickim oraz zgorzeleckim. Wysokie wartości były także charakterystyczne dla miasta Wrocławia i Legnicy oraz powiatu oleśnickiego. W wypadku pierwszej grupy jednostek terytorialnych jest to wynikiem funkcjonowania na ich obszarze dużych przedsiębiorstw związanych z przemysłem wydobywczym i energetycznym. Na obszarze powiatów lubińskiego i polko- 
wickiego bardzo wysokie przychody generują kopalnie i zakłady przetwórcze miedzi należące do KGHM, a w przypadku powiatu zgorzeleckiego PGE Kopalnia Węgla Brunatnego „Turów” i PGE Elektrownia „Turów”.

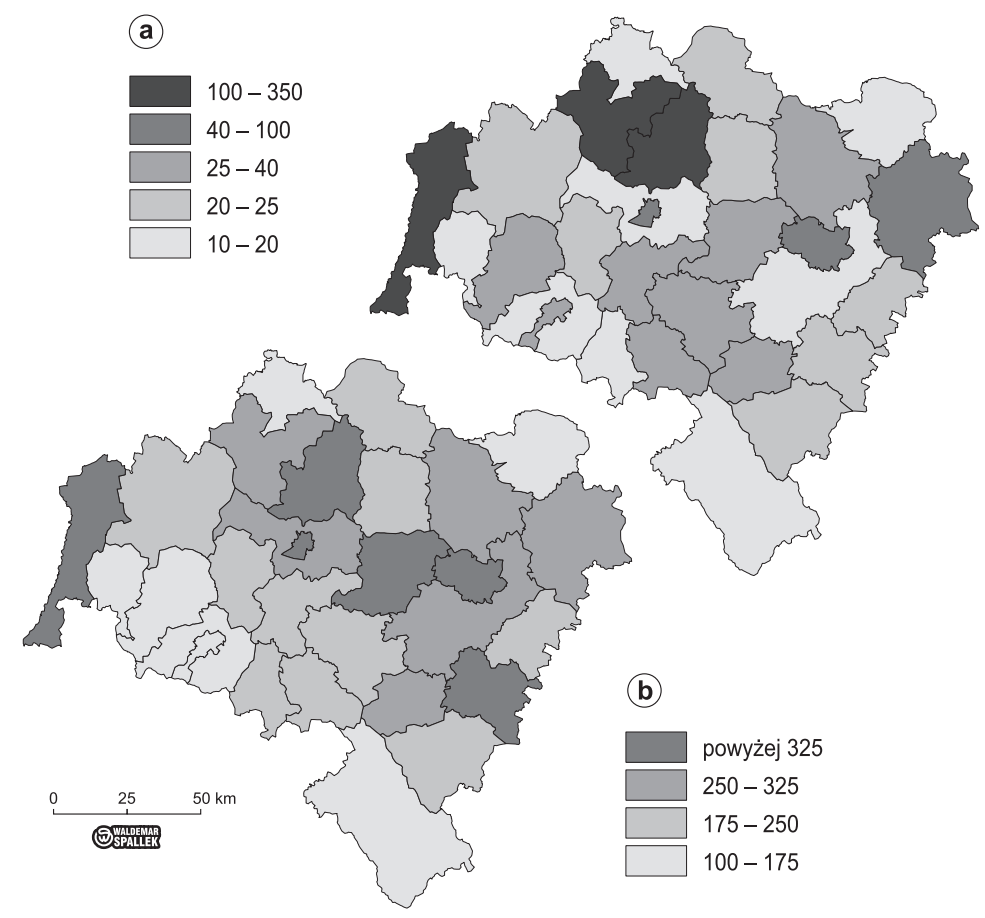

Ryc. 6. Przeciętna wartość przychodów ze sprzedaży: a - w mln zł na 1 firmę korporacyjną, $\mathrm{b}-\mathrm{w}$ tys. zł na 1 zatrudnionego w firmie korporacyjnej

Źródło: opracowanie własne na podstawie: Baza firm... (2007)

Wysokie wartości uzyskiwane w wypadku drugiej grupy jednostek, szczególnie dla Wrocławia i Legnicy, sąjuż efektem funkcjonowania na ich obszarze mocno zdywersyfikowanych co do rodzajów działalności podmiotów. Nie bez znaczenia jest tu podstrefa Legnickiej Specjalnej Strefy Ekonomicznej w Legnicy, która uzyskuje wysoką pozycję wśród stref w Polsce w zakresie dokonanych nakładów inwestycyjnych (szerzej Brezdeń, Spallek 2008). Wysokie wartości przychodów zaobserwowane w powiecie oleśnickim są natomiast efektem funkcjonujących na jego obszarze nowych podmiotów gospodarczych związanych z przemysłem motoryzacyjnym, spożywczym i meblarskim. Na uwagę zasługują także powiaty: wałbrzyski, świdnicki i dzierżoniowski. Obszary te należały przed okresem transformacji do najbardziej uprzemysłowionych na Dolnym Śląsku. Pomimo przeżywanych trudności, na bazie wcześniejszych ich struktur gospodarczych po restrukturyzacji utrzymały się na rynku dawne przedsiębiorstwa lub powstały nowe firmy korporacyjne o dobrym standingu.

Najniższe wartości analizowanego wskaźnika występowały m.in. w powiatach: lubańskim, kamiennogórskim, jeleniogórskim i legnickim, co może wynikać z niezakończonych jeszcze przekształceń ich lokalnych gospodarek, związanych szczególnie z przemysłem metalowym czy włókienniczym. 
Nieco odmienny układ przestrzenny ma miejsce w wypadku wskaźnika ukazującego relację wartości przychodów ze sprzedaży na 1 zatrudnionego w firmie korporacyjnej (ryc. 6b). Jego najwyższe wartości są charakterystyczne dla Wrocławia i powiatów położonych w bliskim sąsiedztwie aglomeracji wrocławskiej. Zwraca uwagę wysoka efektywność zatrudnienia w firmach powiatów średzkiego i strzelińskiego, na obszarze których w ostatnich latach pojawiło się kilka znaczących inwestycji z udziałem kapitału zagranicznego. Wspomniane inwestycje w znacznym stopniu determinują wysoką efektywność czynnika pracy firm korporacyjnych na wskazanych obszarach. Na uwagę zasługuje także powiat wrocławski uzyskujący korzystniejsze relacje w zakresie wartości przychodów na 1 zatrudnionego niż wartości przychodów na 1 firmę korporacyjną. Wspomniany powiat charakteryzuje się dużą dynamiką przyrostu podmiotów gospodarczych, w tym także korporacyjnych, co jest efektem swoistego „wylewania się” działalności gospodarczej z obszaru Wrocławia. Wiele $\mathrm{z}$ tych podmiotów w badanym okresie znajdowało się we wstępnych fazach swojej działalności charakteryzującej się jeszcze stosunkowo niskimi wartościami przychodów, ale o wysokim stopniu ich efektywności. Wysoka efektywność przychodów przypadająca na 1 zatrudnionego występowała także w powiatach związanych z LGOM oraz w powiecie zgorzeleckim.

Znaczne przestrzenne zróżnicowanie w województwie miało miejsce także w wypadku wskaźników ukazujących relację zyskowności na 1 firmę i zyskowności na 1 zatrudnionego (ryc. 7). Można jednak zaobserwować zaznaczające się w regionie dwa obszary koncentracji firm uzyskujących najkorzystniejsze relacje wymienionych wskaźników. Pierwszy obszar,

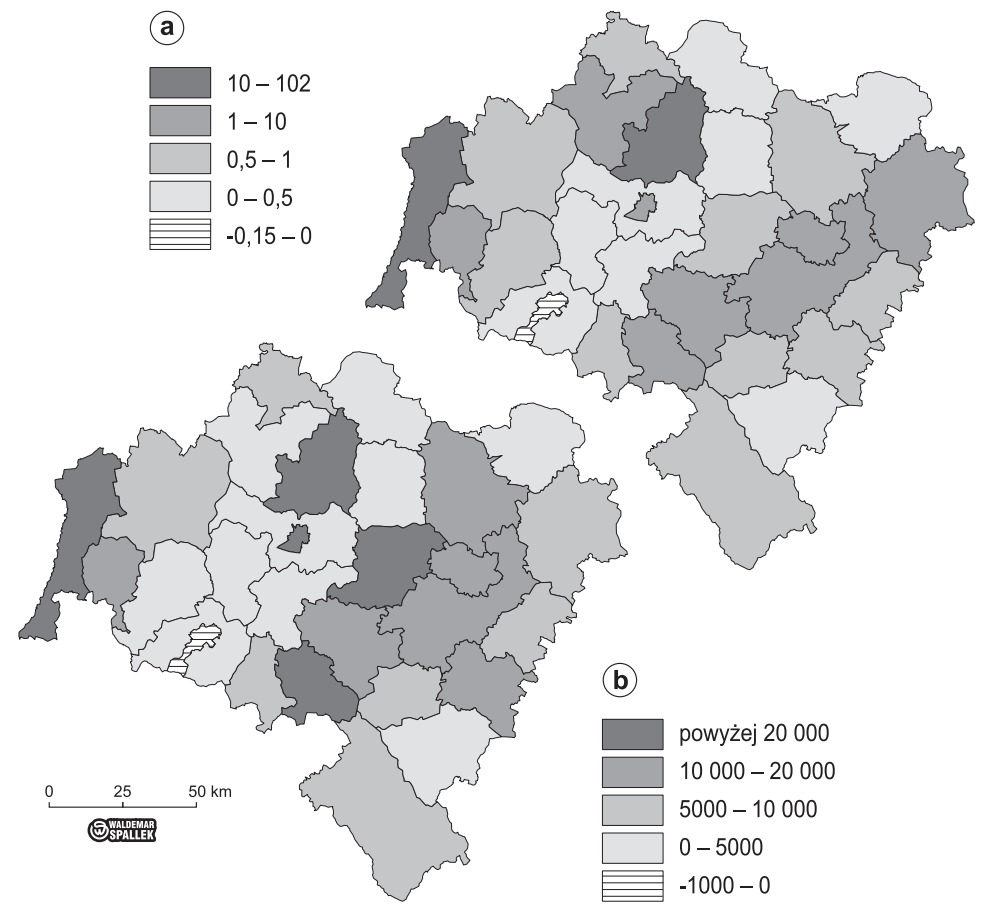

Ryc. 7. Przeciętna zyskowność: a - w mln zł na 1 firmę korporacyjną, $\mathrm{b}-\mathrm{w}$ tys. zł na 1 zatrudnionego w firmie korporacyjnej 
silniej wykształcony, obejmujący powiaty: trzebnicki, Wrocław, wrocławski, średzki, świdnicki, wałbrzyski, wraz z otoczeniem o stosunkowo niższym poziomie efektywności, tworzonym przez powiaty: oleśnicki, oławski, dzierżoniowski, kamiennogórski. Drugi obszar słabiej wykształcony jest związany z powiatami: lubińskim, polkowickim, bolesławieckim, lubańskim i zgorzeleckim.

W zakresie omawianych wskaźników szczególną uwagę zwraca powiat wałbrzyski. Korzystne relacje odnośnie poziomu zyskowności przypadającej na 1 firmę korporacyjną oraz poziomu zyskowności przypadającej na 1 zatrudnionego na obszarze tego powiatu wykazują firmy zlokalizowane na obszarze Wałbrzyskiej Specjalnej Strefy Ekonomicznej „Invest-Park”, a więc na obszarze stosunkowo nowych przedsięwzięć inwestycyjnych. Ujemne wartości dla obu wskaźników wystąpiły natomiast dla badanych podmiotów z obszaru Jeleniej Góry. Ta niekorzystna sytuacja była wynikiem wykazywanej dużej straty na działalności przez Jeleniogórskie Zakłady Farmaceutyczne Polfa, które w omawianym okresie były przejmowane przez litewskiego inwestora strategicznego Sanitas.

Podstawowym elementem funkcjonowania każdego podmiotu jest osiaganie zysku. Powinien on się kształtować w określonej proporcji do zaangażowanych kapitałów oraz do wielkości uzyskanych przychodów i poniesionych kosztów. Intensywność rentowności mierzy się relacją zysku do wielkości zaangażowanego kapitału. Jej poziom ustala się relacją zysku do wielkości poniesionych kosztów lub osiaganych przychodów ze sprzedaży (Ćwiąkała-Małys, Maksimowicz 1997). Badanie rentowności wyspecjalizowanej grupy podmiotów, jaką jest w tym wypadku zbiorowość firm korporacyjnych o dobrym standingu, może więc dotyczyć relacji uzyskanej zyskowności do zrealizowanego na jej rzecz przychodu ze sprzedaży.

Analiza przestrzenna powyższego wskaźnika (ryc. 8) pozwala stwierdzić, iż najwyższa efektywność przychodów omawianych firm występuje w powiatach, na obszarze których

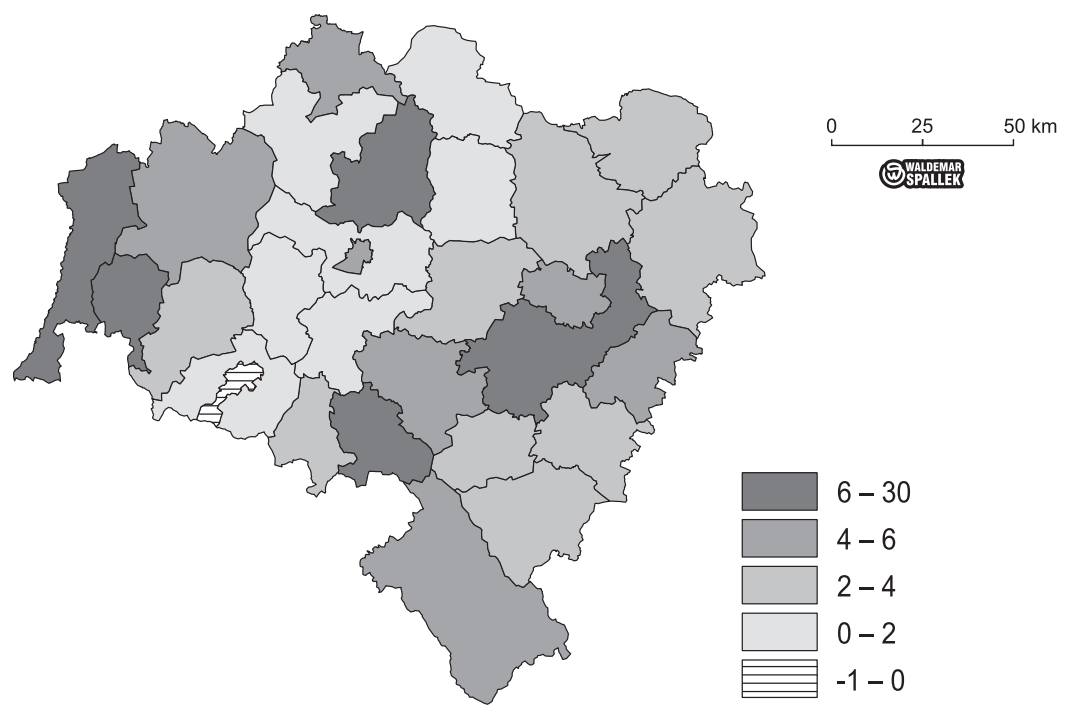

Ryc. 8. Wskaźnik rentowności sprzedaży mierzony relacją zyskowności do przychodów firm korporacyjnych w \%

Źródło: opracowanie własne na podstawie: Baza firm... (2007). 
są zlokalizowane wielkie przedsiębiorstwa związane z górnictwem i przetwórstwem miedzi (powiat lubiński, częściowo Legnica) lub górnictwem węgla kamiennego i energetyką (powiat zgorzelecki). Istotny wpływ na obraz badanej efektywności firm korporacyjnych w województwie mają także nowe przedsięwzięcia produkcyjne charakteryzujące się lepszym gospodarowaniem czynnikami wytwórczymi (powiat wrocławski, wałbrzyski, częściowo Legnica).

Wskazane prawidłowości znajdują pewne potwierdzenie w wypadku kolejnego wskaźnika, jakim jest rentowność kapitału własnego analizowanych firm. Jest to relacja zyskowności do kapitału własnego badanej zbiorowości podmiotów o dobrym standingu. (ryc. 9). Najwyższe wartości wskaźnika rentowności kapitału wynoszące od 30 do 65 \% występowały w firmach zlokalizowanych na obszarze powiatów: wrocławskiego, wałbrzyskiego, lubińskiego, lubańskiego i Legnicy, a dodatkowo (w stosunku do efektywności przychodów) także w powiatach trzebnickim i bolesławieckim. W powyższych powiatach funkcjonowały więc firmy charakteryzujące się najkorzystniejszą sytuacją finansową. Stwarza ona możliwość uzy-

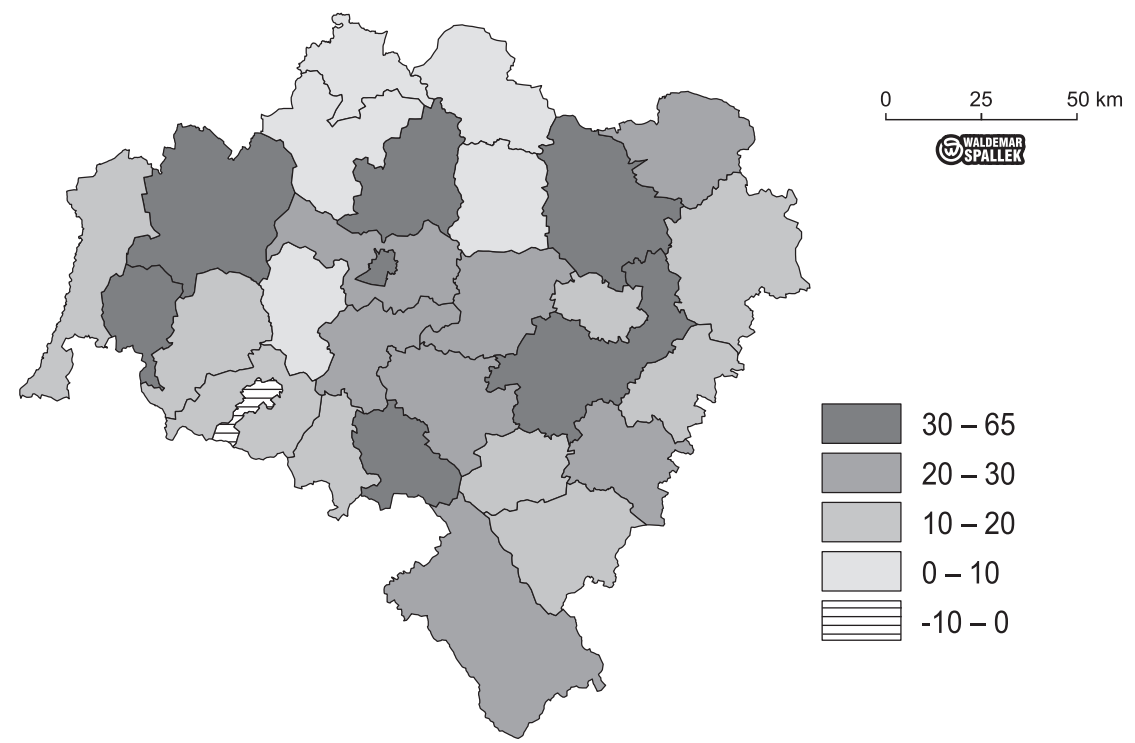

Ryc. 9. Wskaźnik rentowności kapitału własnego, czyli relacja zyskowności do kapitału własnego w \%

Źródło: opracowanie własne na podstawie: Baza firm... (2007)

skiwania wyższych dywidend w takich podmiotach oraz podstawy do dalszego ich rozwoju.

Gęstość firm korporacyjnych o dobrym standingu wykazuje wyraźny związek z gęstością zaludnienia. Zwiększającej się gęstości zaludnienia odpowiada bowiem zwiększająca się gęstość badanych podmiotów (ryc. 10). Prawidłowość o podobnym charakterze ma miejsce pomiędzy natężeniem firm korporacyjnych o dobrym standingu mierzonym liczbą analizowanych firm przypadających na 10 tys. mieszkańców a gęstością zaludnienia (ryc. 11).

$\mathrm{Na}$ rozkład przestrzenny badanych firm ma również wpływ poziom wyposażenia w infrastrukturę techniczną oraz położenie powiatów. Określenie poziomu wyposażenia 


\section{liczba osób na \\ $1 \mathrm{~km} \mathrm{kw}$.}

\section{liczba firm na} $100 \mathrm{~km} \mathrm{kw}$.

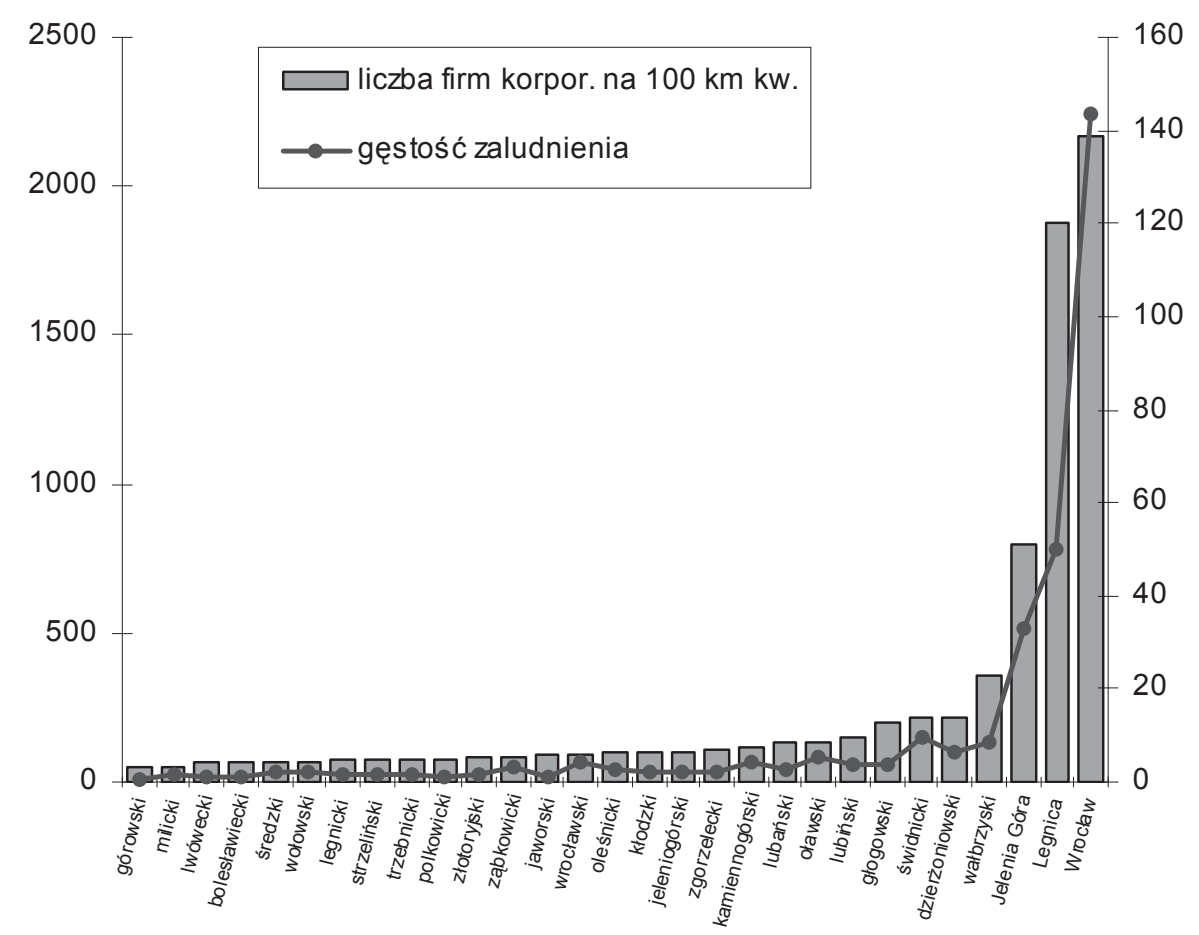

Ryc. 10. Gęstość firm korporacyjnych o dobrym standingu i gęstość zaludnienia w powiatach województwa w $2006 \mathrm{r}$.

Źródło: opracowanie własne na podstawie: Baza firm... (2007) oraz Województwo dolnoślqskie. Podregiony... (2007).

w infrastrukturę techniczną $\mathrm{w}$ poszczególnych powiatach oraz ich ocenę położenia dokonano za pomocą metody punktowej, w której poszczególnym cechom przypisywano punkty proporcjonalnie do ich wartości. Pojęcie infrastruktura techniczna zostało potraktowane w sposób tradycyjny, jako zespół podstawowych urządzeń technicznych warunkujących lokalizację działalności produkcyjnej. Stąd w jej skład wchodzą nie tylko uzbrojenie terenu w urządzenia wodno-kanalizacyjne, lecz także sieć obsługi transportowej i telekomunikacyjnej (Chojnicki 1999). Wartościami cech, które oceniano w powiatach województwa, były: długość sieci wodociagowej na km², długość sieci kanalizacyjnej na $\mathrm{km}^{2}$, długość sieci gazowej na km², przepustowość oczyszczalni ścieków na 1000 mieszkańców, liczba abonentów telefonii stacjonarnej na 1000 mieszkańców, sieć drogowa, z uwzględnieniem obecności drogi wojewódzkiej, drogi dopuszczonej do ruch ciężkiego (do 10 t na oś), drogi krajowej, węzła autostradowego, odległości od granicy zachodniej i od lotniska międzynarodowego. Wartości cech oceniano w skali od 1 do 6 punktów. Wzrastającej ocenie wyposażenia powiatów w infrastrukturę techniczną i ich położenia towarzyszy zwiększające się natężenie występowania firm korporacyjnych o dobrym standingu (ryc. 12). 

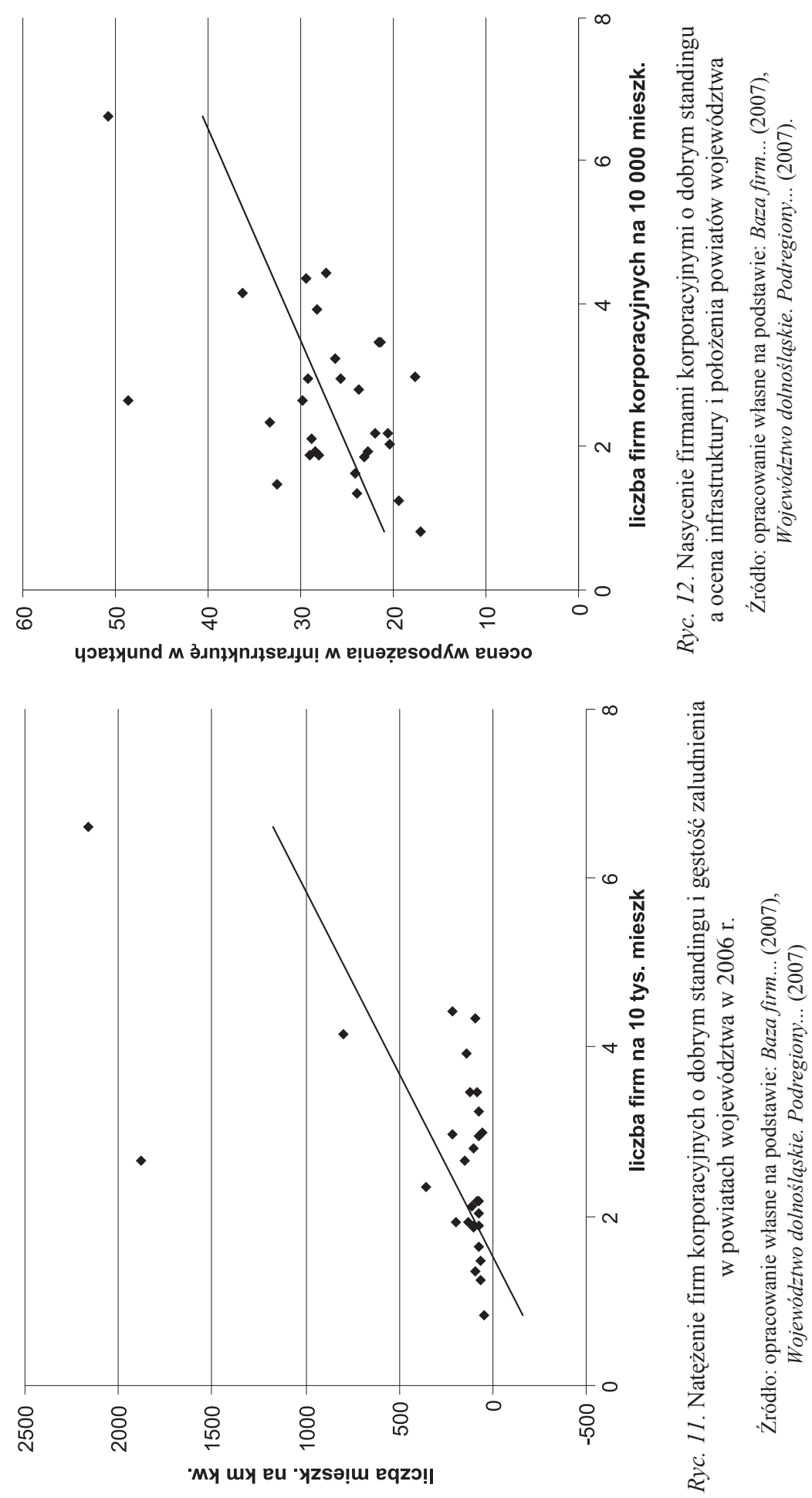


\section{Podsumowanie}

Firmy korporacyjne o dobrym standingu stanowią znaczącą cześć podmiotów gospodarczych województwa dolnośląskiego osiągających przychody powyżej $5 \mathrm{mln}$ zł. Z tego względu należą one do istotnych uczestników procesów gospodarczych przebiegających na rynkach lokalnych badanego regionu. Posiadanie przez powyższe firmy dobrej reputacji handlowej wynika z ich korzystnie ocenianej sytuacji finansowej i wiarygodności kredytowej. Stwarza ona potencjalne możliwości na uzyskiwanie przez te firmy zewnętrznych źródeł finansowania w postaci różnorodnych produktów kredytowych. Mogą zostać one wykorzystane na realizację procesów inwestycyjnych zwiększających nie tylko poziom wyposażenia majątkowego omawianych podmiotów i lokalnych gospodarek, ale także przyczyniających się do zwiększenia atrakcyjności inwestycyjnej całego regionu.

Rozmieszczenie firm korporacyjnych o dobrym standingu na obszarze województwa dolnośląskiego charakteryzuje się ich znacznym przestrzennym zróżnicowaniem. Największe natężenie ma miejsce w części wschodniej województwa. Znaczne przestrzenne zróżnicowanie dotyczy także poziomu efektywności ich funkcjonowania z zaznaczającymi się dwoma pasami najwyższej rentowności. Istotny wpływ na przestrzenny rozkład efektywności funkcjonowania tych firm mają bardzo duże podmioty z sektora paliwowo-energetycznego i górnictwa miedzi oraz nowe przedsięwzięcia inwestycyjne.

Istnieje silna zależność pomiędzy gęstością analizowanych firm i ich natężeniem a gęstością zaludnienia. Na rozkład przestrzenny firm ma także wpływ poziom wyposażenia w infrastrukturę techniczną i położenie powiatów.

\section{Literatura}

Baza firm o dobrym standingu w 2006 r., 2007, Wywiadownia Gospodarcza Coface InterCredit, Warszawa.

Brezdeń P., Spallek W., 2008, Specjalne strefy ekonomiczne w przestrzeni gospodarczej województwa dolnoślaskiego, [w:] Procesy transformacji układów przestrzennych przemystu na tle zmieniajacego się otoczenia, red. Z. Zioło, T. Rachwał, Prace Komisji Geografii Przemysłu PTG, nr 10, Warszawa-Kraków, s. 217-229.

Budnikowski A., Kawecka-Wyrzykowska E., 1996, Międzynarodowe stosunki gospodarcze, PWE, Warszawa.

Chojnicki Z., 1999, Podstawy metodologiczne i teoretyczne geografii, Bogucki Wydawnictwo Naukowe Poznań.

Ćwiąkała-Małys A., Maksimowicz Z., 1997, Wybrane zagadnienia analizy ekonomicznej w podmiocie gospodarczym, Wyd. Uniwersytetu Wrocławskiego, Wrocław.

Jaworski W.L., Krzyżkiewicz Z., Kosiński B., 2003, Bank. Rynek, operacje, polityka, Wyd. Poltext, Warszawa.

Pierścionek Z., 1998, Strategie rozwoju firmy, PWN, Warszawa.

Podmioty gospodarcze wedlug rodzajów i miejsc prowadzenia działalności w 2006 r., 2007, GUS, Warszawa.

Województwo dolnoślqskie. Podregiony, powiaty, gminy w 2007, 2007, Urząd Statystyczny we Wrocławiu. 


\section{Economic effectiveness of corporate firms of good standing in Dolnośląskie Voivodship in spatial perspective}

The paper presents the spatial diversity of economic effectiveness of corporate firms in the Dolnośląskie Voivodship (region). Research was conducted for local units of the region; it was based on Coface Intercredit data. The volume of total turnover, the profit, employment, and trade relations were analysed.

Authors try to indicate conditioning of activity of the corporate firms in the region in the spatial perspective. They present the position of the Voivodship in Poland in terms of the studied parameters.

Research of economic effectiveness of the specific kind of enterprises is now carried out with difficulty. It is because of the lack of available and reliable data. Ambiguity of accepted criteria of identification is the next problem of indicating the corporate firms. In the paper the criterion of client segmentation by financial institutions is used. And that is why in the paper economic effectiveness is presented only for units, whose total profits are more than 5 million zlotys.

The corporate firms are of great importance in the local as well as state economy. They contribute to the economic increase of areas of their activity. They might contribute to the investment attractiveness of these areas too.

dr Paweł Brezdeń

dr Waldemar Spallek

Uniwersytet Wrocławski

e-mail: brezden@geogr.uni.wroc.pl

e-mail: spallek@geogr.uni.wroc.pl 